\title{
A SALA DE AULA INVERTIDA: NARRATIVAS DE EXPERIÊNCIAS DE PROFESSORES QUE ATUAM NA EDUCAÇÃO SUPERIOR
}

\author{
Aléssio Adrian Chiuratto, Universidade da Cidade de São Paulo - UNICID.
} professoralessio@gmail.com

\section{RESUMO}

Atuei como Coordenador dos Cursos de T.I. em uma Universidade Privada que estava implantando o modelo da Aula Invertida com base no sistema AVA- Ambiente Virtual de Aprendizagem. Como estava familiarizado com o novo método, fui convidado para ministrar um treinamento interno aos docentes que estavam sentindo dificuldades em se apropriar dos princípios e técnicas do referido modelo. A participação nesse treinamento me oportunizou conhecer melhor meus colegas de trabalho e me aproximar de suas experiências profissionais e refletir sobre suas dificuldades diante do modelo da sala de aula invertida. O presente trabalho surge nesse contexto e tem como objetivo: desenvolver um blog que possibilite debates e reflexões sobre a metodologia da aula invertida com base nos autores, Pierre Lévy, Bergmann e Sams. Para o desenvolvimento do blog, foi necessário retomar a discussão sobre o Modelo da Aula Invertida, realizar grupos focais com professores que utilizam esse modelo e analisar as narrativas produzidas, com base nos autores, Delory Momberger, Jovchelovich, Josso, Fulanetto, Schutze e Morgan. As narrativas dos professores apontam para algumas questões que merecem ser aprofundadas: as dificuldades em utilizar o Sistema AVA, principalmente no que se refere às aulas práticas, não envolvimento dos alunos que precisam também serem formados nessa nova metodologia, a falta de estrutura de trabalho para os professores que não dispõe de tempo para preparar suas aulas e a necessidade do professor rever sua maneira de trabalhar, o que demanda estudo e pesquisa. O blog procura, além de fornecer informações técnicas, criar espaço para que essas e outras questões que por ventura surgirem, sejam debatidas.

Palavras-chave: Metodologias Ativas. Sala de Aula Invertida. Bricolagem. Aprendizagem na tecnologia.

Data de recebimento: $21 / 01 / 2021$

Data do aceite de publicação: 15/04/2021

Data da publicação: 30/04/2021 


\title{
THE INVERTED CLASSROOM: NARRATIVES OF EXPERIENCES OF TEACHERS WHO WORK IN HIGHER EDUCATION
}

\author{
Aléssio Adrian Chiuratto, Universidade da Cidade de São Paulo - UNICID. \\ professoralessio@gmail.com
}

\begin{abstract}
I acted as Coordinator of the Courses of T.I. in a Private University that was implanting the Inverted Class model based on the AVA system - Virtual Learning Environment. As I was familiar with this new method, I was invited to give in-house training to teachers who were having difficulty in appropriating the principles and techniques of the model. Participating in this training gave me the opportunity to get to know my work colleagues better and to get closer to their professional experiences and reflect on their difficulties with the inverted classroom model. The present work arises in this context and aims to develop a blog that allows debates and reflections on the methodology of the inverted class based on the authors, Pierre Lévy, Bergmann and Sams. For the development of the blog, it was necessary to retake the discussion about the Inverted Class Model, to hold focal groups with teachers that use this model and to analyze the narratives produced, based on the authors, Delory Momberger, Jovchelovich, Josso, Furlanetto, Schutze and Morgan. The teachers' narratives point to some issues that merit deepening: the difficulties in using the AVA System, especially with regard to practical classes, not involving students who need to be trained in this new methodology, the lack of a work structure for teachers who do not have time to prepare their classes and the teacher's need to revise their way of working, which demands study and research. The blog seeks, in addition to providing technical information, create space for these and other issues that may arise, are debated.
\end{abstract}

Keywords: Active Methodologies. Inverted Classroom. DIY (do it yourself). Learning in technology.

\section{INTRODUÇÃO}

No início de minha carreira profissional, tive a oportunidade de trabalhar em algumas Instituições bancárias e permaneci neste segmento por 19 anos. Na busca de crescimento profissional, passei por alguns departamentos dentro dessas Instituições e, por consequência, realizei várias atividades. Em uma dessas atividades, me deparei com a necessidade de elaborar treinamentos para os gerentes das agências bancárias. Para isso, 


\section{A SALA DE AULA INVERTIDA: NARRATIVAS DE EXPERIÊNCIAS DE PROFESSORES QUE ATUAM NA EDUCAÇÃO SUPERIOR}

estudava os produtos do banco, construía uma apresentação objetiva e, de acordo com os propósitos da Instituição, realizava o treinamento previsto. Essa experiência me aproximou do exercício da docência e me instigou a refletir e registrar minha prática por meio do desenvolvimento de material a ser utilizado nos cursos. Esses treinamentos tinham como objetivo capacitar os gerentes por meio da apresentação dos produtos e do esclarecimento das dúvidas que por ventura surgissem. A cada treinamento terminado, eu me sentia realizado e com uma sensação de estar no lugar certo, o que me impelia a aprimorar meu trabalho. No entanto, esses treinamentos não eram constantes, o que me fez sentir estimulado a migrar para a carreira de professor em busca de novas experiências como docente. Pierre Lévy (1999) salienta que cada vez mais os indivíduos são levados a mudar de profissão pois no decorrer de suas trajetórias profissionais entram em contato com competências variadas, o que os leva a reorientar suas carreiras de forma que possam exercê-las e desenvolvê-las. Foi o que aconteceu comigo: conviver com colegas, discutir nosso trabalho e as maneiras de como exercê-lo me abriu novos horizontes profissionais relacionados com a docência.

Na ocasião, recebi um convite para trabalhar em uma faculdade. Como eu não tinha uma especialização na área de Educação, ao mesmo tempo em que comecei a lecionar, iniciei, na mesma faculdade, um curso de Pós-Graduação em docência para o Ensino Superior. No referido curso, me deparei com as metodologias ativas, que buscavam desenvolver a autonomia individual do aluno, sua disponibilidade para trabalhar em grupos e sua capacidade de refletir e tomar decisões. $\mathrm{O}$ encontro com essa metodologia levou-me a experimentar novas maneiras de organizar o trabalho docente e discente em sala de aula, o que fez com que me deslocasse do lugar do professor que transmite conhecimentos, para aquele que, com base em novos dispositivos didáticos, busca transformar a sala de aula em um laboratório de aprendizagens.

Ao final deste curso de Pós-Graduação, em 2015, decidi dar continuidade aos meus estudos e entrei para o Mestrado Profissional em Formação de Gestores Educacionais, da Universidade da Cidade de São Paulo. Ao realizar um trabalho final da disciplina Narrativas (auto)biográficas: pesquisa e formação, fui instigado a rever minha trajetória de formação. Para isso, me apoiei nas tecnologias de comunicação que me eram familiares para compor um site: "Desenhando o futuro por meio do passado", no qual

\footnotetext{
1 Disponível no endereço eletrônico: https://memoria-e-identidade.webnode.com 


\section{A SALA DE AULA INVERTIDA: NARRATIVAS DE EXPERIÊNCIAS DE PROFESSORES QUE ATUAM NA EDUCAÇÃO SUPERIOR}

postei um diário sobre as aulas e uma narrativa sobre minha vida acadêmica, como resultado de um trabalho para apresentação dessa disciplina.

Durante a realização do Mestrado, fui convidado a lecionar nos cursos de T.I. em outra Instituição de Educação Superior (IES). Cumpre destacar que meu interesse em tecnologia vem antes mesmo da possibilidade de eu poder comprar um computador. Retomando minha trajetória, recupero lembranças de objetos que desmontei por querer entender como funcionavam. Desmontei desde brinquedos a carros, provocando muitas vezes a ira de meu pai, que me culpava por danificar os objetos, mas na maioria das vezes eu conseguia recuperá-los. Questionava-me sobre o que poderia melhorar naquele objeto para depois explicar aos outros, como suas possibilidades de funcionamento, compartilhando, assim, minhas descobertas.

Enfim, minha curiosidade despertava a cada equipamento adquirido, independentemente do tamanho ou função do objeto, e isso ocorre até os dias atuais. Comecei a ser chamado na família de Bob Construtor, personagem de um desenho que consertava tudo que parava de funcionar. Hoje posso dizer que era um bricoleur, palavra francesa utilizada para nomear "um faz tudo que lança mão das ferramentas disponíveis para realizar uma tarefa" (KINCHELOE \& BERRY, 2007).

Ao iniciar minhas atividades docentes na nova Instituição de Educação Superior (IES), fui surpreendido pelo fato da Universidade estar começando a implantar o modelo de sala de aula invertida, utilizando o sistema AVA (Ambiente Virtual de Aprendizagem), o qual comentarei mais adiante, como suporte para sua implantação.

O modelo da aula invertida, "Flipped Classroom", sistematizado por Jon Bergmann e Aron Sam (2012), consiste inicialmente em disponibilizar via internet o conteúdo das aulas de forma antecipada para que os alunos possam se preparar para o trabalho que será desenvolvido na sala de aula presencial. As atividades pedagógicas que seriam realizadas fora da sala de aula, passam a ser realizadas presencialmente, com a mediação do professor. Cumpre destacar que, com o decorrer do tempo, esse modelo foi sendo aperfeiçoado e modificado por aqueles que passaram a utilizá-lo.

Portanto, novamente me deparei com uma metodologia ativa, mas que agora se apoiava nas novas tecnologias. Nessa perspectiva, mais uma vez me senti mobilizado a aprofundar meus conhecimentos a esse respeito. Para isso, me permite montar e remontar esse método de forma a compreender como é o seu funcionamento e quais possibilidades ele oferecia para aprimorar minha prática. Percebi também que ele possibilita lançar mão 


\section{A SALA DE AULA INVERTIDA: NARRATIVAS DE EXPERIÊNCIAS DE PROFESSORES QUE ATUAM NA EDUCAÇÃO SUPERIOR}

de diversas ferramentas tecnológicas que, ao serem incluídas, potencializam o fazer pedagógico.

Novamente vivi um processo de bricolagem (KINCHELOE \& BERRY, 2007). Para os autores, os bricoleurs se propõem a compreender a complexidade que envolve objetos, como também processos. Nessa perspectiva, a bricolagem existe a partir do pressuposto pela complexidade do mundo real. Ele busca interagir com o mundo em busca de ir para além das representações moldadas consciente ou inconscientemente pela cultura, as quais proporcionam um quadro que destaca ou oculta o que pode ser observado. Para tecer esse movimento não basta olhar para o mundo à distância e repetir o que dele se fala, é necessário interagir com ele brincando, desmontando e remontando e, talvez, dessa forma se aproximar do que as crianças fazem quando querem se apropriar da realidade na qual vivem.

Vivemos em uma sociedade na qual o avanço tecnológico se dá de forma cada vez mais rápida, as tecnologias de informação se inserem nas diferentes esferas sociais, impactando o cotidiano dos indivíduos e das sociedades. Atualmente, não se pode mais prescindir das novas tecnologias e nem abrir mão de seu potencial no que se refere à produção de conhecimento e à intercomunicação social e no que se refere às suas contribuições que tangem a educação, cada vez mais desafiada a incluí-las nos espaços pedagógicos.

A tendência é que o ensino presencial se mescle com o ensino a distância. Isso já pode ser observado em diversas Instituições de Educação Superior (IES) que lançam novas opções de disciplinas on-line a cada semestre. Como salienta Pierre Lévy:

Os especialistas nesse campo reconhecem que a distinção entre ensino "presencial" e ensino "a distância" será cada vez menos pertinente, já que o uso das redes de telecomunicação e dos suportes multimídia interativos vem sendo progressivamente integrado às formas mais clássicas de ensino (Lévy, 1999, p. 170).

Nessa perspectiva, é importante que sejam realizados estudos que abordem como está se dando a implantação de metodologias que incluam as novas tecnologias na Educação, pois muito há de se refletir sobre as implantações de novos métodos de ensino com apoio tecnológico, seja esse apoio por internet, mídia, multimídia, TV, ensino a distância. Além disso, é importante dar uma atenção ao processo de implantação junto aos professores e alunos, considerando que serão esses os principais responsáveis pelo sucesso ou não da aprendizagem pautada em meios tecnológicos. Para Pierre Lévy (1999, p. 169): "Será necessário, portanto, buscar encontrar soluções que utilizem técnicas 


\section{A SALA DE AULA INVERTIDA: NARRATIVAS DE EXPERIÊNCIAS DE PROFESSORES QUE ATUAM NA EDUCAÇÃO SUPERIOR}

capazes de ampliar o esforço pedagógico dos professores e dos formadores". Por mais avançado que um projeto sistêmico educacional seja, ainda sem compreender seu funcionamento por parte dos professores e alunos, pouco provável será o sucesso de sua finalidade no ensino.

Apesar da importância da inclusão das tecnologias na Educação, observei que grande parte dos meus colegas não parecia tão entusiasmada como eu frente à nova proposta, viam-na com desconfiança, considerando-a não um desafio que poderia potencializar seu trabalho, mas um acréscimo de tarefas. Essa constatação me impactou, pois todos lecionávamos num curso de T.I., o que nos fazia ter familiaridade com as tecnologias de informação e conhecer os seus benefícios, principalmente no que se refere ao seu potencial para gerir tarefas.

Como eu era Coordenador dos Cursos de T.I. e estava utilizando com certa facilidade o novo método, fui convidado para ministrar um treinamento interno aos docentes que estavam sentindo dificuldades em se apropriar dos princípios e técnicas do modelo da aula invertida. A participação nesse treinamento me oportunizou conhecer melhor meus colegas de trabalho e me aproximar de suas experiências profissionais e refletir sobre suas dificuldades diante do modelo da sala de aula invertida.

Cumpre destacar que aprendi a utilizar as ferramentas do sistema sozinho, minha curiosidade e exploração foram os meios que utilizei para compreender e dominar o sistema. A Instituição disponibiliza vídeos explicativos sobre o método de ensino e como utilizar as ferramentas, mas esses não estabeleciam relações com a prática. Esse material me ajudou a explorar e compreender melhor as bases nas quais o modelo de aula invertida, se sustentava, mas não davam suporte para resolver muitas das questões que os professores faziam a respeito do modelo, e foi aí que comecei a perceber onde e como poderia colaborar no processo de formação docente, entendendo tais dificuldades.

Com as datas e horários do treinamento estabelecidos e publicados, juntaram-se professores de vários cursos e os professores de T.I. no laboratório de informática da Instituição. Como já havia atendido alguns professores na própria sala dos professores explicando sobre o funcionamento e utilização das ferramentas, já era esperado que as dificuldades dos professores de cursos de Humanas poderiam ser maiores, e que os professores de T.I.

Com o andamento do treinamento, comecei a fazer anotações sobre as dúvidas e dificuldades relatadas pelos professores, de forma a organizá-las por categoria para 


\section{A SALA DE AULA INVERTIDA: NARRATIVAS DE EXPERIÊNCIAS DE PROFESSORES QUE ATUAM NA EDUCAÇÃO SUPERIOR}

facilitar a abordagem delas nos espaços de formação. As dificuldades dos professores iam desde como navegar no sistema, apesar dele fornecer muitas informações de como fazêlo, até como utilizá-lo para trabalhar com os conteúdos de suas disciplinas em sala de aula. Observei que todos os professores, mesmo os de T.I., demonstraram dificuldades para utilizar e entender o sistema e o método de ensino, isso foi o ponto de partida para aplicar o treinamento.

Com base nessa experiência, foram surgindo algumas questões que ao suscitar respostas me ajudaram no delineamento do trabalho:

- Quais fatores contribuem para que os professores de cursos de T.I. resistam à implantação de metodologias ativas que se apoiam nas T.I. na sala de aula?

- Quais fatores poderiam colaborar para a utilização de metodologias ativas que se apoiam nas T.I. por parte dos professores?

Visando ampliar o conhecimento a respeito do tema realizei uma revisão de literatura no Banco de Dissertações e Teses da Capes entre março de 2017 e outubro de 2017, tendo com anos base 2014, 2015, 2016, 2017 e 2018, utilizei como palavra-chave: aula invertida. Com base nessa revisão, foi possível constatar a existência de 52 (cinquenta e duas) dissertações de mestrado e não localizei em doutorado

Observei que a maioria dos estudos discute a utilização das metodologias ativas, aula invertida e a inserção das novas tecnologias no ambiente escolar. Especificamente, localizei 2 (dois) trabalhos que investigam a percepção dos professores e dos alunos a respeito do trabalho realizado com a aula invertida, os quais são: Milhorato (2016) com título: "Desafios e possibilidades da implantação da metodologia sala de aula invertida: estudo de caso em uma IES privada, cujo o objetivo principal foi identificar as vantagens e as dificuldades na aprendizagem dos sujeitos envolvidos no processo sala de aula invertida. Milhorato (2016) faz a pesquisa com 305 (trezentos e cinco) alunos da graduação participantes do novo modelo, por meio de 36 (trinta e seis) questionários e utiliza as entrevistas com 8 (oito) docentes da graduação envolvidos no processo de implantação odo novo modelo na Unidade Venda Nova da Faculdade Pitágoras. O segundo trabalho foi a de Borges (2017) intitulado "O planejamento por competências no ensino superior: uma análise da percepção dos professores", realizada na UNOPAR (Universidade Norte do Paraná), essa foi a que mais se aproximou do tema de minha dissertação. Essa pesquisa teve como objetivo "analisar e revelar, a percepção dos professores no Fórum de capacitação do modelo KLS 2.0, sugerindo propostas com 


\section{A SALA DE AULA INVERTIDA: NARRATIVAS DE EXPERIÊNCIAS DE PROFESSORES QUE ATUAM NA EDUCAÇÃO SUPERIOR}

prevalência da pedagogia ativa" (Borges 2017). Nessa perspectiva discutiu e analisou a metodologia da aula invertida e as novas formas de ensinar e aprender, considerando o estudante neste cenário ter de apresentar uma postura mais ativa, no contexto dos três tempos didáticos (pré-aula, aula e pós-aula). Os sujeitos dessa pesquisa foram os professores do campus em Paraná, e os dados foram coletados em um fórum de discussão situado no sistema AVA, utilizado para implantar a aula invertida, e a pesquisa contou com uma amostragem de 1.000 (um mil) participantes.

Com base na revisão de literatura, pude constatar que o método da aula invertida é um objeto que merece ser melhor investigado, considerando que ele está sendo adotado por diversas Instituições de Educação Superior (IES) e ainda existe um número pequeno de estudos a respeito.

Nessa perspectiva, a pesquisa assume como objetivo principal:

- Desenvolver um blog com base nas narrativas dos professores dos cursos de T.I. da educação superior, que possibilite debates e reflexões sobre a metodologia da aula invertida.

Como objetivos específicos propõem:

- Discutir a metodologia da aula invertida;

- Descrever a metodologia da pesquisa, pautada na pesquisa autobiográfica com narrativas e no procedimento de produção de dados: grupo focal;

- Analisar as narrativas de professores no sentido de compreender os desafios que enfrentam ao implantarem o modelo da aula invertida.

Esta dissertação conta com a Introdução, três capítulos e com as considerações finais. No primeiro capítulo (1), são abordados os princípios que dão sustentação ao modelo da aula invertida e exponho o Sistema AVA que dá sustentação a sua implantação. No segundo capítulo (2), discute-se os traçados metodológicos da pesquisa. No terceiro capítulo (3), é apresentada a análise dos dados, e nas considerações finais, sintetizo os principais resultados da pesquisa.

\section{A AULA INVERTIDA (FLIPPED CLASSROOM)}

Este capítulo tem por objetivo fazer um breve sobrevoo sobre os princípios que estruturam o método de sala de aula invertida. Flipped Classroom (FC), e no ambiente virtual de aprendizagem - AVA. 


\section{A SALA DE AULA INVERTIDA: NARRATIVAS DE EXPERIÊNCIAS DE PROFESSORES QUE ATUAM NA EDUCAÇÃO SUPERIOR}

\subsection{A aula invertida}

O método de sala de aula invertida, é um modelo que se pauta no ensino híbrido. O ensino híbrido, conhecido como blended learning ou b-learning, teve sua proposta desenvolvida a partir de experiências e-learning. Bergmann e Sams (2016) afirmam que a abordagem combina aprendizagem por projetos, por descoberta, baseada no interesse dos alunos. Os alunos formulam um problema da vida real e gerenciam soluções que exigem pesquisas para serem elaboradas.

Para Bergmann e Sams (2016), inverter a sala de aula significa basicamente o seguinte: o que tradicionalmente é feito em sala de aula agora é executado em casa e o que tradicionalmente é feito como trabalho de casa agora é realizado em sala. Já Suhr $(2015,2016)$, entende que a ideia da sala de aula invertida propõe uma forte conexão entre momentos presenciais e outros virtuais, de autoestudo, mediados por meios tecnológicos de comunicação, por exemplo: o sistema AVA. Esse processo possibilita que o aluno desempenhe o papel de sujeito de sua própria aprendizagem e que o professor, por sua vez, assuma o papel de mediador para que o aluno consiga, partindo de seus conhecimentos prévios, construir conhecimentos científicos. Nesse sentido, Freire, sinaliza que:

Como situação gnosiológica, em que o objeto cognoscível, em lugar de ser o término do ato cognoscente de um sujeito, é o mediatizador de sujeitos cognoscentes, educador, de um lado, educandos, de outro, a educação problematizadora coloca, desde logo, a exigência da superação da contradição educadoreducandos. Sem esta, não é possível a relação dialógica, indispensável à cognoscibilidade dos sujeitos cognoscentes, em torno do mesmo objeto cognoscível (Freire, 1970, p. 39).

Dessa forma, a mediação da aula pelo professor por meio da aula invertida, tornase o foco da aprendizagem e da problematização para o alcance do conhecimento entre os alunos, superando os moldes de uma educação conservadora.

Para Freire (1970), desta maneira, o educador já não é o que apenas educa, mas o que, enquanto educa, é educado, em diálogo com o educando que, ao ser educado, também educa.

Nos anos 90, os estudos e a utilização desse modelo de aula concentravam-se, principalmente, na Educação Superior. Durante o ano de 2004, uma contribuição importante sobre sala de aula invertida tem início com Salman Khan, da Khan Academy, que desenvolveu estratégias de ensino a distância, num primeiro momento via telefone, 


\section{A SALA DE AULA INVERTIDA: NARRATIVAS DE EXPERIÊNCIAS DE PROFESSORES QUE ATUAM NA EDUCAÇÃO SUPERIOR}

para sua prima dar aulas de reforço a seus alunos (KHAN, 2013). Essas estratégias tinham a finalidade de auxiliar os alunos, otimizar o tempo e minimizar de alguma forma as lacunas deixadas pelo ensino regular. Na sequência, Khan criou um programa de computador simples, com intuito de gerar problemas matemáticos para que os alunos resolvessem esses exercícios sem limites de tentativas, com o intuito de que se apropriassem dos conceitos referentes aos conteúdos propostos.

No Ensino Médio, Bergmann e Sams, em 2007 e 2008, começaram os trabalhos com suas turmas usando as gravações das aulas postadas em um ambiente virtual de aprendizagem, para acesso, principalmente, de alunos atletas que não podiam comparecer nas aulas devido às competições, e para facilitar a retomada dos conteúdos, possibilitando aos alunos avançar, recuar e parar os vídeos quando desejassem.

A FLN, ou Flip Learning Network ${ }^{2}$, sistematizada em 2012 por um grupo de professores americanos, entre eles Jon Bergmann e Aaron Sams, que atualmente conta com mais de 25 mil educadores, é um dos espaços virtuais para educadores interessados em aprender mais sobre a sala de aula invertida. Trata-se de uma comunidade on-line sem fins lucrativos, na qual educadores de todo o mundo podem compartilhar e acessar recursos, dicas, ferramentas e muito mais. São iniciativas como estas que estão favorecendo muitas escolas e universidades a trabalharem com o conceito de sala de aula invertida, na medida em que fornecem apoio no âmbito de aprendizagem e qualidade de ensino.

Muitas das mais conceituadas universidades no mundo utilizam a sala de aula invertida como método de ensino, dentre elas, Universidade de Harvard, Massachutsetts Institute of Tecnology (MIT), Duke, Stanford. A sala de aula invertida também está presente em países como Canadá, Holanda, Finlândia, Portugal. Em Harvard, por exemplo, o aprendizado foi $79 \%$ mais eficiente do que os que cursaram o ensino tradicional. Já na Universidade de Michigan, um estudo revelou que os alunos aprenderam em menos tempo (SPITZCOVSKY, 2015).

Está aumentando a utilização da sala de aula invertida em escolas e universidades de todo mundo, implementada por meio de iniciativas públicas e particulares. Exemplos dessas iniciativas foram os programas implantados em Portugal entre 2007 e 2010, o

\footnotetext{
${ }^{2}$ Disponível em: <https://flippedlearning.org>. Acesso em: março de 2017.
} 


\title{
A SALA DE AULA INVERTIDA: NARRATIVAS DE EXPERIÊNCIAS DE PROFESSORES QUE ATUAM NA EDUCAÇÃO SUPERIOR
}

Programa Plano Tecnológico ${ }^{3}$. Nos Estados Unidos a aula invertida é utilizada com muito sucesso:

\begin{abstract}
Os casos de sucesso da Sala de Aula Invertida são uma realidade em Instituições dos Estados Unidos. Na Universidade de British Columbia, por exemplo, professores de Física, dentre os quais fazia parte Carl Wieman, prêmio Nobel de Física em 2001, aplicaram a metodologia e conseguiram um aumento em $20 \%$ na presença e em $40 \%$ na participação. Além disso, as notas dos alunos participantes foram duas vezes maiores que as das classes que utilizaram a metodologia tradicional. Já em Harvard, professores de matemática conduziram um estudo de 10 anos em suas classes de cálculo e álgebra, através do qual descobriram que alunos inscritos em aulas invertidas obtiveram ganhos de 49 a $74 \%$ a mais na aprendizagem que alunos inscritos em aulas tradicionais (SPITZCOVSKY, 2015, seção Conheça o novo conceito da sala de aula invertida).
\end{abstract}

A Figura 1 a seguir faz um comparativo entre o método tradicional e a sala de aula invertida buscando explicitar as diferenças existentes entre os métodos.

Figura 1 - Modelo de Sala de Aula Invertida.

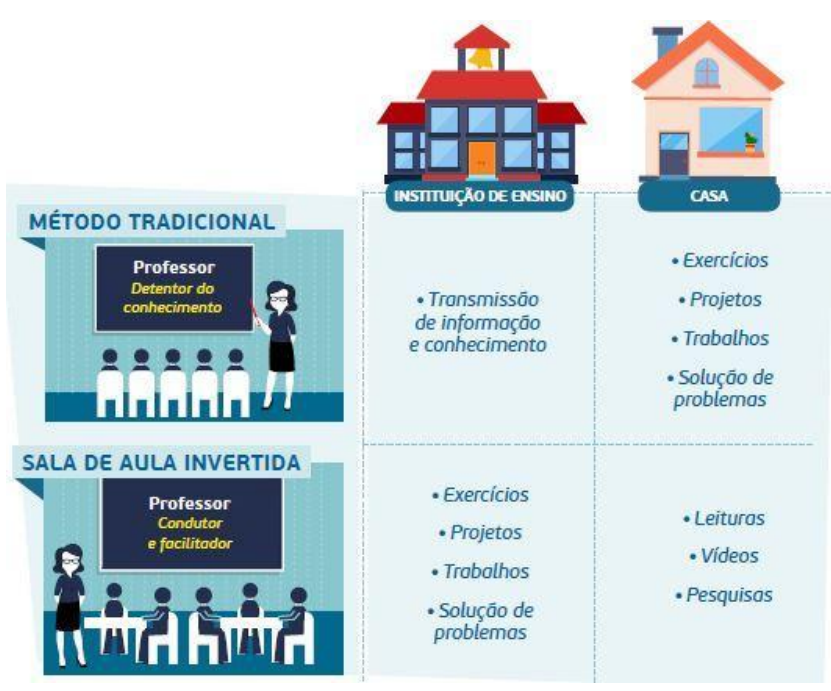

Fonte: Sala de Aula Invertida. Disponível em:

bibliotecadigital.fgv.br/ojs/index.php/ei/article/download/57632/56174. Acesso em: 10 fev. 2017

Figura 2 - Habilidades Cognitivas no Sistemas AVA

“O Plano Tecnológico da Educação (PTE) é o programa do Governo Português para a modernização tecnológica das escolas portuguesas. O PTE promove a integração e a utilização generalizada das TIC nos processos de ensino e de aprendizagem e na gestão e segurança escolares." In http://www.pte.gov.pt/pte/PT/topo/faqs/. Acesso em: março de 2017. 


\section{A SALA DE AULA INVERTIDA: NARRATIVAS DE EXPERIÊNCIAS DE PROFESSORES QUE ATUAM NA EDUCAÇÃO SUPERIOR}

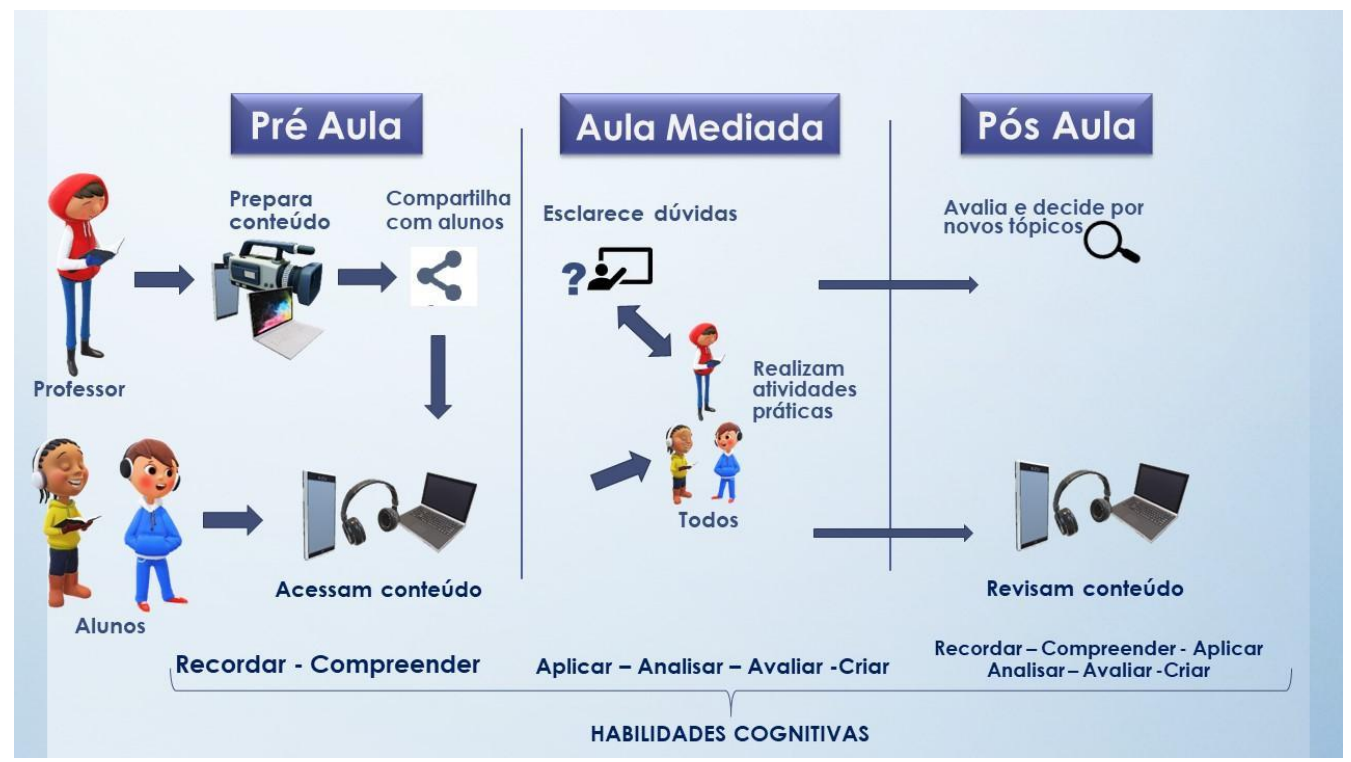

Fonte: desenvolvida pelo autor.

A Figura 2 apresenta a Aula Invertida em seus 3 momentos personalizados no sistema AVA: Pré-Aula, Aula Mediada e Pós-Aula, e mostra como são trabalhadas as habilidades cognitivas em cada um desses momentos. A sala de aula invertida prevê o acesso ao conteúdo antes da aula pelos alunos e o uso dos primeiros minutos em sala para esclarecimento de dúvidas, de modo a sanar equívocos antes dos conceitos serem aplicados nas atividades práticas mais extensas no tempo de classe (BERGMANN \& SAMS, 2012, 2016). Em classe, as atividades se concentram nas formas mais elevadas do trabalho cognitivo: aplicar, analisar, avaliar, criar, contando com o apoio de seus pares e professores.

Transferir palestras (exposição do conteúdo) ou informação básica para fora da sala de aula possibilita ao aluno preparação prévia para atividades de aprendizagem ativa durante a aula, o que ajuda os estudantes a desenvolverem sua comunicação e habilidades de pensamento de ordem superior (LAGE, PLATT \& TREGLIA, 2000).

A nota não é mais o que está em jogo, a falta de um componente do grupo tem relação direta com o restante dos colegas e isto adquire peso na atitude de muitos deles. Nas situações em que o engajamento é menor por parte de um aluno, o próprio grupo tende a cobrar o engajamento, pois a performance do grupo depende de todos. Isso permite ao professor atuar como mediador e criar uma relação mais próxima com os alunos, menos autoritária e de confiança (MORÁN, 2015). Aparta-nos daquela imagem de professor que oferta dados e textos, certamente valiosos, mas que alienam o aluno ao esperar dele uma resposta única e cotas de aprendizagem reguladoras. 


\section{A SALA DE AULA INVERTIDA: NARRATIVAS DE EXPERIÊNCIAS DE PROFESSORES QUE ATUAM NA EDUCAÇÃO SUPERIOR}

\section{O AMBIENTE VIRTUAL DE APRENDIZAGEM - AVA}

Como apoio ao método da aula invertida, a Instituição em que está sendo desenvolvida a pesquisa, utiliza uma plataforma denominada AVA. Entende-se por Ambiente Virtual de Aprendizagem "todo espaço multirreferencial de aprendizagem onde são potencializadas as possibilidades de autoria e colaboração", (BURHNAM et al, 2012, p. 147), isto é, locais sistematizados virtualmente para construção coletiva de conteúdos onde todos são autores nesse processo construtivo.

O AVA adequa acesso a informações em diferentes formas; promove a influência mútua entre os sujeitos, de forma a criar ambientes dialógicos que busquem o desenvolvimento da colaboração mútua; permite um processo de mediação pedagógica que solicite o desenvolvimento da autonomia do sujeito; constitui-se em ambiente instigador de forma a propiciar ao usuário estabelecer relações entre o conhecimento adquirido e as recentes informações, elaborando suas redes de significação para a ampliação do conhecimento.

Existem dois modelos de aulas para que os professores possam utilizar como ferramentas tecnológicas, que são:

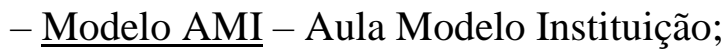

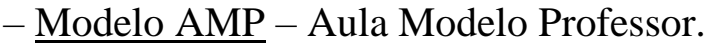

No modelo AMI, a Instituição disponibiliza os conteúdos das disciplinas, enquanto que no modelo AMP, o professor posta os conteúdos de sua disciplina. Em ambos os modelos AMI e AMP, a finalidade é disponibilizar os conteúdos das aulas, que por sua vez são divididas em três momentos (abordados na Figura 2):

- Pré-aula: pauta-se conteúdo da disciplina disponibilizado por meio de textos, mapas conceituais, vídeos e outros materiais e avaliações diagnósticas, que visam preparar o aluno para a aula mediada;

- Aula mediada: momento para estimular o pensamento crítico dos alunos, desenvolver e explanar o conteúdo postado na pré-aula, propício para elaboração de trabalhos em grupos com situações da realidade profissional por meio de situações problema, um fórum de debates mediados pelo professor presencialmente; 


\section{A SALA DE AULA INVERTIDA: NARRATIVAS DE EXPERIÊNCIAS DE PROFESSORES QUE ATUAM NA EDUCAÇÃO SUPERIOR}

- Pós-aula: o conteúdo é revisto e aprofundado a partir das atividades presentes no ambiente virtual.

Cabe a Instituição disponibilizar uma infraestrutura no sistema AVA, salas de aulas e laboratórios com equipamentos adequados, para dar suporte às aulas invertidas, criar condições para que os professores se apropriem de princípios teórico-metodológicos para desenvolver suas aulas, selecionar conteúdos e preparar materiais para utilizar nas aulas. Compete ao professor gerir o processo de acordo com um planejamento prévio, utilizar o material disponibilizado pela Instituição, pelos colegas, bem como preparar o material para suas aulas e motivar e mediar, em suas aulas presenciais, o conteúdo previamente postado para os alunos. Espera-se dos alunos que se preparem para suas aulas presenciais, por meio dos materiais disponibilizados na Pré-aula, participem das atividades em sala de aula e se responsabilizem por suas aprendizagens.

Acredita-se que a tecnologia pode colaborar com o modelo da aula invertida, pois possibilita aos alunos o prévio conhecimento dos conteúdos a serem discutidos pelos professores em sala de aula, amplia o tempo para realização de atividades e projetos no ambiente acadêmico. A partilha e discussão de conteúdos e a colaboração mútua podem desencadear processos de aprendizagem tanto para os alunos como para os professores de qualquer área de conhecimento.

\section{TRAÇADO DA PESQUISA}

Como já mencionado anteriormente, a pesquisa assumiu como objetivo principal desenvolver um blog com base nas narrativas dos professores dos cursos de T.I. da Educação Superior, possibilitando debates e reflexões sobre a metodologia da aula invertida.

Para atingir o objetivo, foi necessário estruturar a pesquisa em duas fases: a) estudo exploratório, b) a construção do blog,

A primeira delas apoiou-se na abordagem qualitativa de pesquisa, que busca desvelar o significado que os sujeitos da pesquisa atribuem a determinado objeto, como intuito de perceber como eles experimentam e como interpretam suas experiências (BOGDAN \& BIKLEN, 1994). Caminhando nessa direção, optou-se por estruturar a pesquisa com base nos princípios da pesquisa narrativa que permitem explorar o ponto de 


\section{A SALA DE AULA INVERTIDA: NARRATIVAS DE EXPERIÊNCIAS DE PROFESSORES QUE ATUAM NA EDUCAÇÃO SUPERIOR}

vista dos colaboradores. A análise das narrativas dos sujeitos da pesquisa forneceu dados importantes que permitiram a construção do blog.

Para o desenvolvimento do blog, optou-se pela utilização do site www.webnode.com, que é uma plataforma on-line para construção e edição de sites e blogs por meio de modelos pré-dispostos neste site. Para criar o blog, foram escolhidos os modelos de telas e imagens dentro do próprio site, selecionadas as disposições dos conteúdos, imagens e textos, mais apropriados para visualização do blog. O site webnode disponibiliza contas de acesso gratuitos e pagos, com opções de ferramentas avançadas no desenvolvimento dos sites e blogs, e foi para essa pesquisa foi adotado o modelo básico e gratuito para edição e criação.

\subsection{Contexto da pesquisa}

A primeira fase da pesquisa foi realizada em uma Universidade privada, em um campus localizado na região metropolitana de São Paulo, no estado de São Paulo. A Universidade é gerida por um grupo empresarial e está presente em quase todo território nacional, somando em torno de 490 mil (quatrocentos e noventa mil) alunos. No campus onde foi realizada a pesquisa são oferecidos cursos de graduação na modalidade presencial e a distância, reconhecidos pelo Ministério da Educação (MEC), bem como cursos de pós-graduação lato sensu (especialização) e de extensão. O referido campus possui uma infraestrutura com biblioteca, anfiteatro com capacidade para 300 pessoas, cantinas, laboratórios de rádio, TV e informática. Atualmente existem em torno de 11.000 (onze mil) estudantes matriculados neste campus, e trabalham no local aproximadamente 230 (duzentos e trinta) professores.

\subsection{Os colaboradores da pesquisa}

Participaram dessa fase da pesquisa quatro professores que atuam nos cursos de T.I. ${ }^{4}$ :

- O professor Alfredo é Mestre em Sistemas de Gestão e atua como docente há mais de 11 anos. Não acumula cargos e não exerce outra atividade. Nascido em 1959, é ao mais velho do grupo, porém não o mais experiente como docente;

\footnotetext{
${ }^{4}$ Os nomes dos professores são fictícios. 


\section{A SALA DE AULA INVERTIDA: NARRATIVAS DE EXPERIÊNCIAS DE PROFESSORES QUE ATUAM NA EDUCAÇÃO SUPERIOR}

- O professor Gerson é Mestre em Engenharia de Produção e atua como docente há mais de 5 anos. Não acumula cargos e não exerce outra atividade. Atualmente leciona para outras Instituições de Educação Superior (IES) particulares;

- A professora Laura é Mestre em Engenharia de Produção e atua como docente há mais de 21 anos. Não acumula cargos e não exerce outra atividade. Atualmente leciona para outras Instituições de Educação Superior (IES) particulares. É a mais experiente como docente no grupo de pesquisa.

- O professor Antônio é Especialista em Ciência da Computação e atua como docente há mais de 11 anos. Leciona para outras Instituições de Educação Superior (IES) e acumula cargo trabalhando como consultor de T.I. para uma empresa privada.

Esses professores possuem idade superior a trinta e cinco anos e têm formação superior nos cursos de T.I. São especialistas, mestres e/ou doutorandos na área de T.I. e lecionam a mais de 5 anos para cursos de graduação.

Os professores selecionados participaram de um treinamento sobre a metodologia da aula invertida dentro do campus da Instituição, e voluntariamente aceitaram o convite para participar do grupo focal desta pesquisa. Os professores que participaram da pesquisa são contratados pelo regime CLT e trabalham nos horários matutinos e/ou noturnos.

\subsection{Procedimento da coleta de dados}

Os dados foram coletados por meio da aplicação de um grupo focal. Para Powell e Single (1996, p. 449), “um grupo focal é um grupo de pessoas selecionadas e reunidas por pesquisadores para discutir e comentar um tema, que é o objeto de pesquisa, a partir de sua experiência pessoal". O grupo terá um foco, que guiará a discussão realizada no grupo. Segundo Morgan e Krueger (1993), a pesquisa com grupos focais tem por objetivo captar, a partir das trocas realizadas no grupo, conceitos, sentimentos, atitudes, crenças, experiências e reações, de um modo que não seria possível com outros métodos. Ainda assim, o trabalho com grupos focais permite compreender processos de construção da realidade por determinados grupos sociais.

Para que os professores se sentissem motivados e confiantes, ao convidá-los para a pesquisa, foram colocados a par do objetivo do estudo e, no dia do encontro para o grupo focal, foi retomada a relevância deste projeto. Antes de iniciar a gravação de áudio 


\section{A SALA DE AULA INVERTIDA: NARRATIVAS DE EXPERIÊNCIAS DE PROFESSORES QUE ATUAM NA EDUCAÇÃO SUPERIOR}

e vídeo, procurei deixar todos os participantes à vontade, abordando conversas informais e testando os equipamentos para a gravação. Dessa forma, todos já estavam acostumados com a gravação e não precisavam se preocupar com as falas e o volume no tom de voz, já que os equipamentos estavam funcionando normalmente.

O encontro teve a duração média de uma hora e trinta minutos, ocorreu na biblioteca dentro da Instituição em que trabalham, o que facilitou conciliar os horários.

Busquei seguir um roteiro pré-estabelecido a fim de manter o foco e alcançar os objetivos da pesquisa. As questões norteadoras no grupo focal foram:

- Já se depararam com fonte de informações e estudos sobre a "sala de aula invertida"?;

- Quando você ouviu falar sobre a necessidade de se adaptar aos novos métodos de ensino, como reagiu diante disso?;

- Falem sobre suas experiências com a aula invertida;

- O que facilitou e o que dificultou a utilização dessa metodologia por parte de vocês?;

- Há algo mais que vocês gostariam de dizer?

Durante o transcorrer do grupo, procurei deixar os participantes à vontade para narrar aquilo que julgassem importante. As discussões que ocorreram no grupo focal foram gravadas em áudio e vídeo e, por sua vez, o material foi transcrito com fidelidade na íntegra.

\subsection{Procedimento de análise dos dados}

Para a análise dos dados produzidos no contexto da pesquisa, me apoiei em alguns pontos da proposta de Schütze (2011), composta dos seguintes passos:

1 - Escutar as narrativas;

2 - Transcrever detalhadamente o material verbal;

3 - Detectar os temas/acontecimentos abordados;

4 - Com base nesses temas, elencar eixos de análise.

Convém destacar que para analisar o material desta pesquisa, utilizei a ferramenta de edição de textos da Microsoft, o Word, em que separei o documento em três colunas: na coluna do centro, inseri a transcrição dos dados; já na coluna da esquerda, destaquei os excertos dos textos que deram suporte para a construção dos eixos de análise; e na 


\section{A SALA DE AULA INVERTIDA: NARRATIVAS DE EXPERIÊNCIAS DE PROFESSORES QUE ATUAM NA EDUCAÇÃO SUPERIOR}

coluna do lado direito, busquei inserir comentários e associações com autores que poderiam colaborar para com a análise dos dados.

\section{ANÁLISE DE DADOS}

O objetivo deste capítulo é apresentar a análise dos dados produzidos, na primeira fase da pesquisa, por meio da reunião do grupo focal após um exame cuidadoso das narrativas dos participantes da pesquisa. A análise dos dados, como já foi salientado, teve início com a leitura das transcrições das falas dos professores. Essa leitura permitiu levantar alguns temas abordados pelos docentes que se transformaram em eixos de análise da pesquisa:

- Sistema AVA;

- Condições de trabalho dos professores;

- O envolvimento dos alunos;

- A necessidade de o professor pesquisar e estudar.

\subsection{Sistema AVA}

Como foi salientado anteriormente, o modelo da aula invertida na Universidade foi introduzido tendo como principal plataforma o Sistema AVA. Frente a esse sistema, os professores se posicionaram:

\footnotetext{
Existe um lado bom, um lado um pouco complicado da coisa, o que eu vejo no AVA, na parte assim de uma matéria teórica, ele vai muito bem. Eu acho que precisa melhorar é quando você tem uma disciplina prática. Eu acho que precisa ser mais estudado, ou na própria ferramenta existir algumas partes, principalmente de infraestrutura, prática, dentro do próprio AVA. Essa é uma dificuldade que eu vejo na parte prática, na teórica ela vai muito bem, pelo menos na minha opinião (ALFREDO).
}

Nessa fala do professor Alfredo, podemos identificar que o Sistema que está sendo utilizado não dá o suporte necessário para o trabalho que estão realizando. Segundo ele, é possível trabalhar com os conteúdos teóricos, mas os conteúdos procedimentais considerados denominados pelos professores de práticos são difíceis de serem abordados. Cumpre destacar que com a disponibilidade do sistema virtual AVA, o professor pode desenvolver e publicar diversos tipos de materiais para os alunos, e é possível trabalhar com este mesmo conteúdo pré-disponibilizado antes e durante o momento da aula, 


\section{A SALA DE AULA INVERTIDA: NARRATIVAS DE EXPERIÊNCIAS DE PROFESSORES QUE ATUAM NA EDUCAÇÃO SUPERIOR}

utilizando para isso procedimentos didáticos, como por exemplo o trabalho com projetos, que possibilita retomar e aplicar os conteúdos vistos anteriormente pelos alunos.

Quanto aos conteúdos por eles considerados como práticos, como montar uma página na internet, estes são difíceis de serem abordados por não existir a possibilidade de inserir outros programas, que no caso possibilitasse desenvolver páginas. Considerando que o AVA só permite postar textos, arquivos, vídeos e links, ele não se presta para esse tipo de conteúdo. Todos os professores do grupo focal destacaram uma contradição: o sistema disponibilizado não se adequa ao trabalho com Tecnologias de Informação, conforme complementam os professores:

Eu também sinto que nas matérias, como o professor Alfredo falou, matérias relativas a redes, eu sinto uma assim, eu acho interessante da parte teórica, eu acho que a gente consegue dar bem (LAURA).

O método, ele é bom, certo? Principalmente, como o companheiro aqui comentou, na questão de matéria teórica, certo? (ANTÔNIO).

A necessidade de outro ambiente para ministrar aulas práticas foi um tema recorrente. Para os professores, o modelo da aula invertida disponibilizado pelo Sistema AVA não se adequa às necessidades dos professores. Conforme a professora Laura reforça, para esse tipo de trabalho seriam necessários laboratórios:

E outra coisa, eu acho, assim, que é uma falha muito grande quando a gente fala: há uma aula no laboratório a cada 15 dias. Para as outras aulas, você só tem sala (LAURA).

A fala dessa professora explicita que as necessidades dos professores não foram consideradas pela Instituição, ao se optar pela aula invertida. Os professores apontam para necessidades que não se aproximam das da Instituição, que no caso não disponibiliza laboratórios de informática em número suficiente para que possam ministrar aulas práticas, importantes para o desenvolvimento dos cursos de T.I.

O que se pode depreender desses depoimentos é que foi disponibilizado um único sistema para todos os cursos da Universidade, sem levar em conta as especificidades de cada um dos cursos, sendo possível observar que há um distanciamento entre as necessidades pedagógicas específicas dos professores de T.I. e o sistema disponibilizado.

Em sua pesquisa, Almeida (2018) destaca que "de acordo com a pesquisa realizada, o moodle como está não atende aos requisitos levantados pelos usuários para aplicação do flipped classroom, sendo necessário organizar e incluir ao sistema algumas funcionalidades". Para os professores pesquisados por Almeida (2018), "alguns detalhes 


\section{A SALA DE AULA INVERTIDA: NARRATIVAS DE EXPERIÊNCIAS DE PROFESSORES QUE ATUAM NA EDUCAÇÃO SUPERIOR}

foram observados por eles e pelos alunos. Por exemplo, implementar a opção de criar chats separados por grupo, para discutir a resolução da tarefa e adicionar a opção de alterar as datas das etapas da tarefa geral, após o seu cadastro".

Nesse sentido, o planejamento educacional necessita de um estreitamento entre os professores e a Instituição.

Cumpre destacar que o sistema AVA é bem aceito e de fácil manuseio e entendimento, trouxe ganhos para os professores, mas ainda carece de adaptações, considerando as especificidades dos cursos, para que possa ser utilizado a contento. Ainda nessa abordagem, os professores reforçam o anseio em participar da construção ou reforma dessa implantação do método:

\footnotetext{
Poderia chamar as pessoas de cada área e opinar. Porque não é só chegar e trazer a ferramenta para o professor. Acho que devia ter um colegiado de cada área e opinar, coletando ajuda dos professores e por área, e colocar o negócio para acontecer (ALFREDO).
}

Eu tenho a impressão que, quem sugere essas ferramentas, não sabe o que éo dia a dia na sala de aula (GERSON).

\subsection{Condições de trabalho}

As Universidades privadas estão passando por reformulações e mudanças que estão afetando as condições de trabalho dos professores, muitas delas têm acarretado a redução da carga horária dos professores, como a introdução de cursos a distância, de disciplinas a distância em cursos presenciais

A introdução do modelo de aula invertida impacta diretamente o trabalho dos professores, como a aula invertida. Essas mudanças, pautadas principalmente nas novas tecnologias, se, por um lado, podem potencializar o trabalho desenvolvido nas salas de aula, por outro - se as condições de trabalho dos professores não forem consideradas -, acabam por sobrecarregar os professores, que para incluí-las no cotidiano pedagógico necessitam de tempo para estudo e preparação de aulas, o que costuma não ser remunerado.

Como em qualquer outra profissão, alguns professores fazem exata e unicamente o que é previsto pelas normas oficiais da organização escolar, ao passo que outros se engajam a fundo num trabalho que chega a tomar um tempo considerável, até mesmo invadindo sua vida particular, as noites, os fins de semana, sem falar das atividades de duração mais longa, como curso de aperfeiçoamento, de formação específica, atividades 


\title{
A SALA DE AULA INVERTIDA: NARRATIVAS DE EXPERIÊNCIAS DE PROFESSORES QUE ATUAM NA EDUCAÇÃO SUPERIOR
}

para escolares ou sindicais, das associações profissionais, dos clubes esportivos para jovens etc. (TARDIF \& LESSARD, 2005, p. 113).

Segundo os professores, a aula invertida vem ocasionando uma sobrecarga de trabalho:

\begin{abstract}
Como na vida tudo tem o positivo e o negativo, o negativo vejo que há uma sobrecarga do professor sobre esse método de pré-aula, aula e pós-aula. Porque você analisa pré-aula, monta a aula, e aí você resolve as questões da pós-aula (ANTÔNIO).
\end{abstract}

Como salienta o prof. Antônio, a aula invertida acarreta para o professor mais trabalho. Exige segundo ele um tempo maior que inclui leitura e preparo de materiais e provavelmente um acompanhamento mais próximo dos alunos. Se na perspectiva tradicional o professor era um transmissor de conteúdo, no modelo da aula invertida seu papel passa a ser revisto:

[...] você se torna o facilitador. Olha, Professor, puxa vida, olha, eu fiz assim, não vai dar certo... É aí onde você usa sua experiência. Por quê? Porque você já fez aquilo, você já passou por aquilo [...] (GERSON).

[...] quando você ver que o aluno está saindo daquele objetivo, cabe ao professor fazer o quê? Botar ele no rumo (GERSON).

O professor em sala de aula se torna um planejador que prepara estratégias e materiais de aprendizagem, um mediador que acompanha os alunos na realização de atividades em sala de aula e um avaliador não só dos alunos, mas também dos processos desenvolvidos para execução da aula como um todo e isso requer uma revisão no que é ser professor por parte de todos, professores e alunos que não estão familiarizados com esses novas propostas.

\subsection{0 envolvimento dos alunos}

Como o método implantado requer a aceitação e comprometimento por parte de todos os envolvidos, uma questão que foi bastante discutida pelos professores diz respeito à participação dos alunos. Os professores dizem se sentir desmotivados, quando preparam as aulas, disponibilizam os materiais e descobrem que os alunos não consultaram e, consequentemente, não se prepararam para as atividades que serão desenvolvidas em sala de aula.

A frustração é quando você chega e vê um relatório que nosso campus $99 \%$ acessa, só que não acessam de boa vontade, acessa forçado (ALFREDO). 


\section{A SALA DE AULA INVERTIDA: NARRATIVAS DE EXPERIÊNCIAS DE PROFESSORES QUE ATUAM NA EDUCAÇÃO SUPERIOR}

Causa uma frustração. Você prepara uma aula que é de invejar, você capricha (ANTÔNIO).

Em busca de se apropriar do novo modelo de aprendizagem, os professores têm se aproximado mais dos alunos, na tentativa de compreender como eles aprendem, quais as estratégias que são mais adequadas para a preparação das aulas:

Porque eu sempre pergunto para o aluno seguinte: qual a metodologia mais acertada? Eu acho, na minha opinião, que eu aplico, eu pergunto para o aluno o seguinte: como você consegue aprender? Desse jeito? Desse? Daquele? Eu trabalho em cima do que ele me responder. Então a chance de eu acertar e fazer o aluno aprender alguma coisa, é maior. Como que você quer que eu te ensino? É com leitura? É com pesquisa? É com projeto? Foi o que aconteceu com pessoal de redes (GERSON).

Esse parece ser um ganho da aplicação do modelo da aula invertida. Professores e alunos não sabem direito como isso funciona e precisam se apoiar em busca de traçar um caminho que seja proveitoso.

A proposta de elaborar um planejamento que se fundamenta na proposta da sala de aula invertida de fazer com que os alunos procurem as informações possibilitando certa liberdade, orientada pelos professores, propicia a autonomia dos alunos. Nesse aspecto, Berbel (2011) destaca que:

\footnotetext{
O engajamento do aluno em relação a novas aprendizagens, pela compreensão, pela escolha e pelo interesse, é condição essencial para ampliar suas possibilidades de exercitar a liberdade e a autonomia na tomada de decisões em diferentes momentos do processo que vivencia, preparando-se para o exercício profissional futuro (Berbel, 2011, p. 29).
}

Contudo, essa autonomia nem sempre é constatada pelos professores. Em sua fala, o professor Antônio transparece a falta de engajamento dos alunos perante o modelo de aula e mostra que esse processo é temporal, para que seja incorporado pelos alunos.

Eu tirei uma estatística esses dias, somente numa turma de 109 alunos, somente 19 acessaram o sistema. Eu não sei se é medo ou se não estão acostumados com método. Acostumado com o método não estão, porque é o primeiro semestre. Então aí eu acho que vai um tempo para entrar na veia deles essa questão desse método (ANTÔNIO).

Então eu posto a pré-aula, eu início cobrando a pré-aula, faço uma enquete de quem assistiu, e raramente dois ou três levantam a mão e falam que assistiu (ANTÔNIO). 


\section{A SALA DE AULA INVERTIDA: NARRATIVAS DE EXPERIÊNCIAS DE PROFESSORES QUE ATUAM NA EDUCAÇÃO SUPERIOR}

Eu concordo com o professor Antônio, que a gente se esforça, faz essa parte de pré-aula e pós-aula, também, e no final os alunos não fazem e não tiram proveito. Vamos dizer de uma classe de 60, quase 70 alunos, e esses 70 alunos nem 19 fizeram (LAURA).

Os professores frente a dificuldade de engajamento dos alunos, fazem tentativas de aproximar os alunos do modelo de aula invertida apoiadas na lógica tradicional de ensino, como atribuir premiações não mencionadas pelo modelo de aula invertida que prevê por parte do aluno um compromisso com seu processo de aprendizagem.

Eles só acessam se você der uma premiação, propor alguma nota ou um ponto. Fora isso, por livre espontânea vontade, eles não acessam, um ou outro só que acessa (ALFREDO).

Contudo, cabe destacar que os alunos não foram preparados para se adequar ao modelo de aula invertida, e o professor tem um papel importante nesse processo de inclusão, independente do plano institucional desenvolver esse conceito de inclusão. Os professores percebem que existe uma cultura escolar incorporada pelos alunos que dificulta sua adaptação ao novo método, como podemos ver no depoimento a seguir:

Então não adianta você ter a melhor ferramenta do mundo, se a cultura do aluno não mudar (GERSON).

Essas metodologias aonde fazem com que o aluno tenha que estudar em casa, isso acaba complicando, porque não é cultura do nosso aluno, com o perfil pesquisador e de curiosidade (GERSON).

Para a professora Laura, a cultura do aluno está associada ao ensino básico e destaca em sua fala:

Vocês estão falando de cultura. Quando eu era criança, eu fui para a escolinha japonesa, não sei se vocês conhecem essa história de escola japonesa? Lá, desde pré-primário, você é ensinado em cima de um conceito do $5 S$, que é qualidade. E lá você tinha que seguir. Você sabia que tinha que fazer as suas disciplinas, ler o texto, ter organização. Então já cria isso aí, desde o básico (LAURA).

Os professores atribuíram também às características das novas gerações a dificuldade de se adaptar ao método proposto.

A metodologia, como professor Antônio falou, eu acho boa também, mas eu acho que esse pessoal, esses alunos dessa geração, eles estão acostumados ao imediatismo. Eles querem receber tudo de mão beijada [...] (LAURA).

É importante considerar que a falta de envolvimento dos alunos com a metodologia pode acarretar uma interrupção do ciclo natural do modelo de aula invertida 


\section{A SALA DE AULA INVERTIDA: NARRATIVAS DE EXPERIÊNCIAS DE PROFESSORES QUE ATUAM NA EDUCAÇÃO SUPERIOR}

para aprendizagem, desanimando os professores que têm que trabalhar mais para desenvolver a proposta, porém não identificam melhoras no resultado esperado.

Se desanima? De certa forma sim. Porque você tem um trabalho, com uma metodologia que você não está vendo o resultado (GERSON).

Ainda em sua fala, o professor Gerson conclui:

Então, eu acho que aqui analisar o perfil do nosso aluno primeiro, antes de você colocar uma metodologia. Porque senão você corre o risco de ter um perfil de aluno que aquela metodologia não serve. Que é o caso, na minha opinião (GERSON).

Implantar um sistema novo na perspectiva dos professores, implica, além de levar em conta as características e necessidades dos professores, levar em conta as dos alunos, pois caso isso não seja considerado existem grandes possibilidades de fracasso no processo.

\subsection{A necessidade do professor pesquisar e estudar}

Neste método de aula invertida, consente que o professor tenha mais liberdade em trabalhar suas práticas, adequando a disciplina às necessidades dos alunos, por meio de processos que são permitidos pelo próprio método de aula invertida, independente da padronização do sistema AVA.

Para o professor Gerson, as experiências e percepções em sua vida profissional o fazem aprimorar o andamento da qualidade de sua aula com foco no aluno:

\footnotetext{
A hora que você ver que o aluno está indo por um caminho errado, cabe ao professor, hoje, já que o conhecimento não está no professor, o conhecimento está na internet, na rede, cabe ao professor, pela experiência que ele tem de empresa, de mercado, de pesquisa, botar ele no rumo. Está saindo, bota ali no rumo com a experiência que você tem. Isso você muda a cultura, mas assim, não vai ser da noite para o dia (GERSON).
}

Notamos que as experiências, nesse caso, marcam a atuação do professor. Para Furlanetto (2003), as matrizes pedagógicas dos professores "representam-se como arquivos existenciais que contém imagens, conteúdos coletivos e pessoais que são acessados quando o professor se exerce nos espaços pedagógicos" (FURNALETTO,2003). 


\section{A SALA DE AULA INVERTIDA: NARRATIVAS DE EXPERIÊNCIAS DE PROFESSORES QUE ATUAM NA EDUCAÇÃO SUPERIOR}

O conhecimento adquirido pelos professores frente ao modelo da aula invertida é destacado como processo de aprendizagem, a fim de poderem adquirir mais conhecimento com as experiências vivenciadas durante o processo de implantação do método. "Esse saber é um saber finito, ligado ao amadurecimento de um indivíduo particular" (LARROSA). Nesse aspecto, o professor Antônio transparece em sua fala que a utilização da ferramenta como método de ensino lhe traz benefícios profissionais, agrega e atualiza novos valores para sua formação como docente e permite ter uma experiência particular.

[...] eu principalmente aprendo também, me atualizo, então eu vejo um ganho aí (ANTÔNIO).

Existe uma facilidade por parte dos professores de T.I. em entender o funcionamento das ferramentas para o método de sala de aula invertida, porém para os professores de outras áreas existe uma dificuldade no manuseio da ferramenta, fazendo com que o impacto diante do método seja maior, aumentando a resistência pelos professores de outras áreas, conforme o relato do professor Alfredo:

Eu acho que o pessoal de T.I., a dificuldade é menos. Coloca na área de Humanas, é complicado para eles, tendo uma metodologia, e de repente muda, de um semestre para outro (ALFREDO).

Mas como obter tal formação perante um momento de implantação e mudanças nas práticas profissionais destes professores? O momento parece ser de adaptação e inovação como desafio para os professores, como relata o professor Alfredo:

O professor tem que estar em primeiro lugar para os alunos, ele tem que ser dinâmico, ele tem que empolgar os alunos (ALFREDO).

Os professores buscam se adequar ao modelo proposto pela Instituição, mas sentem dificuldades e teriam sugestões a fazer no sentido de propor reformulações, no entanto não existe espaço para isso, o que faz com que os professores se sintam excluídos do processo e consequentemente desmotivados. Ao invés de se apossar do processo e realizarem o papel dinâmico e incentivadores do método, eles desistem de continuar tentando.

A formação dos professores diante da implantação desse modelo de aula, como em qualquer situação de mudança, deve ser implantada com planejamento temporal, visando etapas e processos de evolução com acompanhamento constante. 


\title{
A SALA DE AULA INVERTIDA: NARRATIVAS DE EXPERIÊNCIAS DE PROFESSORES QUE ATUAM NA EDUCAÇÃO SUPERIOR
}

Em sua fala, o professor Gerson deixa transparecer a existência de um distanciamento entre o modelo teórico da aula invertida e sua execução, o que dificulta sua implantação o que muitas vezes compromete o desempenho do professor:

\begin{abstract}
Eu fui mal avaliado no avaliar, por quê? Porque no semestre passado a cobrança foi muito forte para o pessoal acessar. A única forma deles acessarem foi o que o professor Alfredo falou, é com barganha. Só estou dando um exemplo da ferramenta aqui, porque nós estamos aqui, mas poderia dar exemplo de outras ferramentas. Por exemplo, não adianta nada você colocar o material lá, você tem que obrigar o aluno a fazer isso, e falar: "pessoal o material está lá, nós vamos discutir o material em sala”. Depois ver quem tem dúvidas. E desse material aqui eu vou gerar trinta, quarenta perguntas, e dessas trinta, quarenta perguntas, dez cairão na prova. Fui criticado por causa disso.
\end{abstract}

Como Valente (1999) salienta: “[...] o professor deverá servir como modelo de aprendiz e ter um profundo conhecimento dos pressupostos teóricos que embasam os processos de construção de conhecimento e das tecnologias que podem facilitar esses processos". No entanto frente às dificuldades o professor, ao invés de desenvolver o papel de mediador, muitas vezes, retoma práticas pedagógicas coercitivas tão presentes em sistemas tradicionais de ensino.

\subsubsection{Avaliações e Flexibilidade na Aula Invertida}

Existem facilidades no modelo da aula invertida que os permite criar modelos avaliativos para as disciplinas, conforme relato dos professores:

\footnotetext{
[...] ]eu consigo montar umas questões teóricas[...] (ALFREDO)

[...]matérias relativas a redes, a parte teórica a gente consegue dar bem. (LAURA).
}

Sobre a metodologia, eu não tenho críticas. Eu acredito, esse novo método é até bom[...] (ANTÔNIO).

A metodologia como professor Antônio falou, eu acho boa também[...] (LAURA).

Segundo Bergmann e Sams (2016), como não existe um modelo único de inversão, em aula o professor pode guiar atividades práticas diferentes ou possibilitar que alunos trabalhem em tarefas diferentes simultaneamente; que trabalhem em grupos ou individualmente ou ainda que sejam avaliados, quando se sentem preparados. 


\section{A SALA DE AULA INVERTIDA: NARRATIVAS DE EXPERIÊNCIAS DE PROFESSORES QUE ATUAM NA EDUCAÇÃO SUPERIOR}

O método da aula invertida, como citado anteriormente, é um método cuja implantação está crescendo no âmbito educacional e traz consigo a flexibilidade de trabalho para os professores, no sentido de práticas e opções para desenvolver os métodos de aula e avaliações.

Moran (2014) considera a sala de aula invertida um dos modelos mais interessantes da atualidade para mesclar tecnologia com metodologia de ensino, pois concentra no virtual o que é informação básica e, na sala de aula, atividades criativas e supervisionadas, uma combinação de aprendizagem por desafios, projetos, problemas reais e jogos. Nesse conceito, o professor Gerson acrescenta:

A questão não é gente discutir a ferramenta, a ferramenta como o próprio nome diz é ferramenta, ela vai te ajudar a fazer alguma coisa que você já sabe fazer, porém ela vai te ajudar a fazer mais rápido, com menos erros, vai tornar aquela atividade mais eficiente.

\section{CONSIDERAÇÕES FINAIS}

Tínhamos como objetivo do presente estudo: desenvolver um blog com base nas narrativas dos professores dos cursos de T.I. da Educação Superior, que possibilitasse debates e reflexões sobre a metodologia da aula invertida. Para isso: inicialmente discutimos a metodologia da aula invertida e, na sequência por meio do grupo focal, buscamos criar um espaço para que professores que estavam vivendo a experiência de trabalhar com a aula invertida tendo como suporte o Sistema AVA, narrassem suas experiências e refletissem sobre elas.

A análise das narrativas permitiu elencar quatro eixos: Sistema AVA; Condições de trabalho dos professores; O envolvimento dos alunos; A necessidade de o professor pesquisar e estudar que, por sua vez, possibilitaram uma compreensão mais profunda das experiências vividas.

Quanto ao sistema AVA, é importante destacar que, segundo os professores, ele se presta ao trabalho com as aulas cujo conteúdo é teórico e não se adequa às disciplinas que desenvolvem conteúdos procedimentais. Surge uma questão que precisa ser levada em conta por aqueles que estão propondo o modelo, bem como pelos professores que o estão utilizando. Como os professores dos cursos de T.I. podem criar um conteúdo de linguagem de programação, por exemplo, para que o estudante possa ler e estudar em casa, sendo que as disciplinas exigem aulas práticas em computadores? Ficou claro que esses professores não foram consultados, quando da implantação do novo método e nem devidamente preparados para a utilização do referido sistema, pois existe a possibilidade 


\section{A SALA DE AULA INVERTIDA: NARRATIVAS DE EXPERIÊNCIAS DE PROFESSORES QUE ATUAM NA EDUCAÇÃO SUPERIOR}

de implantar um programa específico dentro do AVA para que os professores possam utilizar esses programas em suas aulas práticas e eles não se deram conta disso.

Cumpre destacar que o sistema AVA é apontado como de fácil manuseio e entendimento, apesar de carecer de adaptações sinalizadas pelos professores.

Quanto às condições de trabalho docente, detectou-se que a aula invertida traz um aumento de carga de trabalho, ao demandar um tempo maior para o preparo de materiais e para o acompanhamento, individualizado dos alunos. Assim sendo, torna- se torna importante uma revisão do papel dos professores e das suas condições de trabalho, ao se propor o modelo da aula invertida.

Os professores, também, sinalizaram a falta de comprometimento por parte dos alunos, o que acarreta desmotivação por parte dos professores e insatisfação por parte da instituição que não atinge os objetivos propostos.

Por outro lado, os professores disseram que ao tentarem engajar os alunos ao novo método se aproximaram mais deles na tentativa de descobrir como eles estavam se situando frente às novas experiências. Os professores destacaram que, além deles, os alunos, também necessitam ser preparados para a utilização do novo modelo. Foi possível perceber que a aula invertida propõe uma quebra de paradigma no que se refere ao ensino e a aprendizagem, exigindo uma mudança de cultura daqueles que atuam nas instituições escolares. As conversas entre os participantes da pesquisa produziram a consciência de que o modelo precisa ser entendido por todos e que um treinamento pontual não dá sustentação a sua implantação. É necessário, portanto, que haja um acompanhamento sistemático dos envolvidos durante esse processo.

Quanto ao eixo referente à necessidade de o professor pesquisar e estudar, é importante destacar que diante do novo desafio proposto pela instituição, os professores se sentiram desestabilizados, o que fez com que procurassem ampliar seus repertórios para lidar com as novas questões que se ora se apresentavam e, nessa perspectiva, sentiram necessidade de estudar, mas esse processo foi, também, doloroso por estar permeado pela falta de condições para realizar aprofundamentos teóricos. Cumpre destacar que os docentes viveram momentos de adesão, permeados pelo prazer de estar aprendendo, mas também de resistência, por estarem se sentindo explorados por parte da instituição que segundo eles os sobrecarrega de trabalho.

A análise das narrativas dos professores reafirmou o objetivo proposto pelo estudo de criar um blog. Os participantes consideraram a oportunidade de participar do grupo 


\section{A SALA DE AULA INVERTIDA: NARRATIVAS DE EXPERIÊNCIAS DE PROFESSORES QUE ATUAM NA EDUCAÇÃO SUPERIOR}

focal como um espaço formativo e gostariam de ter mais oportunidade para discutir e ouvir outros colegas sobre as questões que emergiram no contexto da pesquisa. Ficou clara, a importância e a necessidade do grupo de trocar experiências sobre o modelo da sala de aula invertida. Os professores, independentemente do curso em que atuam, necessitam de um espaço para uma comunicação colaborativa.

Levando isso em conta montamos o blog, um ambiente virtual, com intuito de disponibilizar um fórum de discussão aberto para os professores da Universidade Anhanguera. O blog denominado: https://focom.webnode.com/, busca ser um espaço no qual os professores possam trocar experiências e postar informações, vídeos, links e demais assuntos que se relacionem com o trabalho realizado com a aula invertida ou com o ambiente AVA. Essa ideia surgiu, uma vez que realizar encontros presenciais com os professores se torna impossível, pois nem todos estão na instituição nos mesmos dias e horários. Nessa perspectiva, a criação do blog, um ambiente virtual que todos podem acessar nos tempos e espaços disponíveis, surge como uma possibilidade de efetivar a troca de experiências e de discutir as dúvidas que emergem durante o trabalho.

Apresentei o projeto do blog para a Coordenação dos Cursos de T.I. da Universidade em que atuo, e houve interesse da parte da instituição pelo projeto, Foi sugerido que ele fosse apresentado à Diretoria da Universidade A Diretoria da Universidade recebeu a proposta com interesse e sugeriu à Superintendência Regional que acolhesse esse projeto, a qual deu apoio à continuidade e acompanhamento do conteúdo deste blog.

Na sequência, apresento algumas das postagens do blog em desenvolvimento:

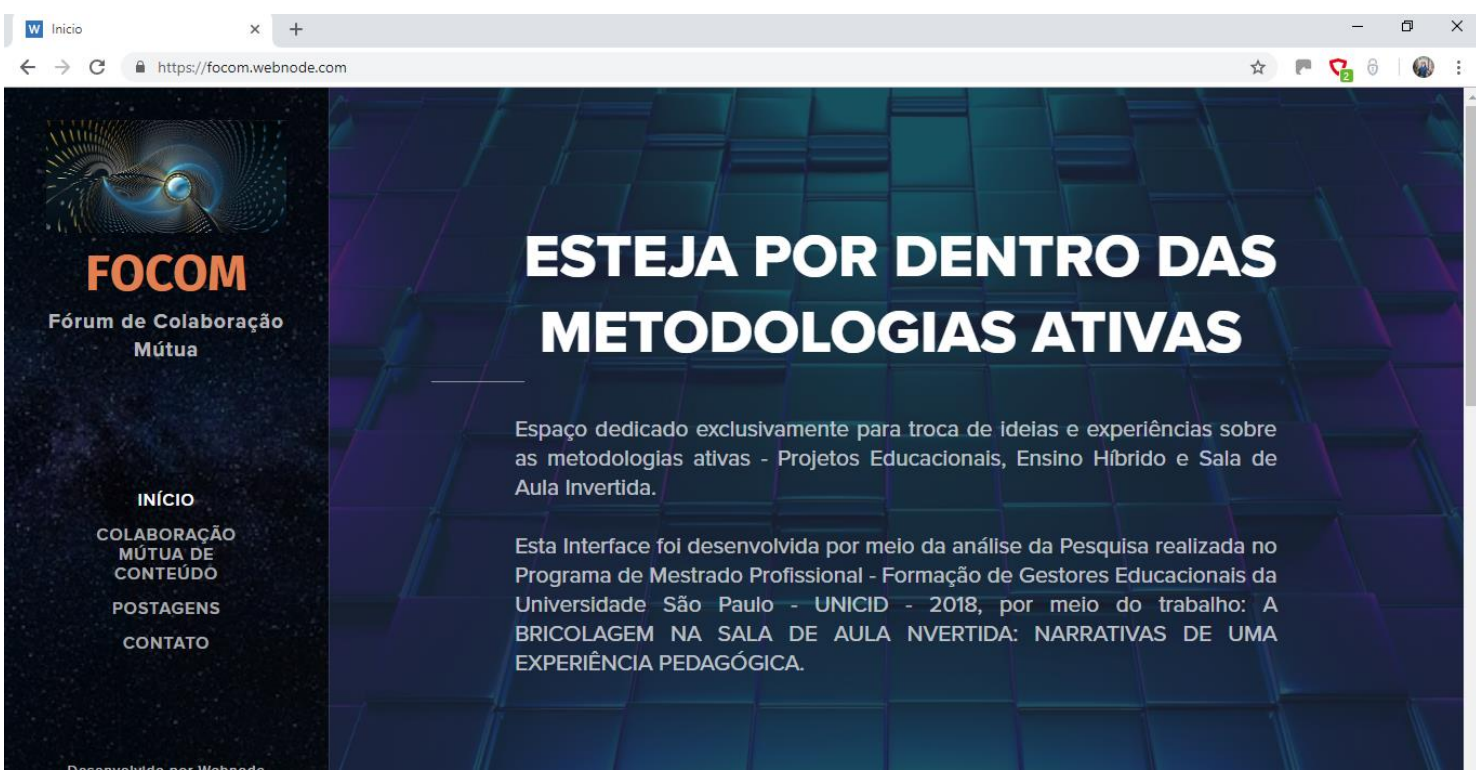




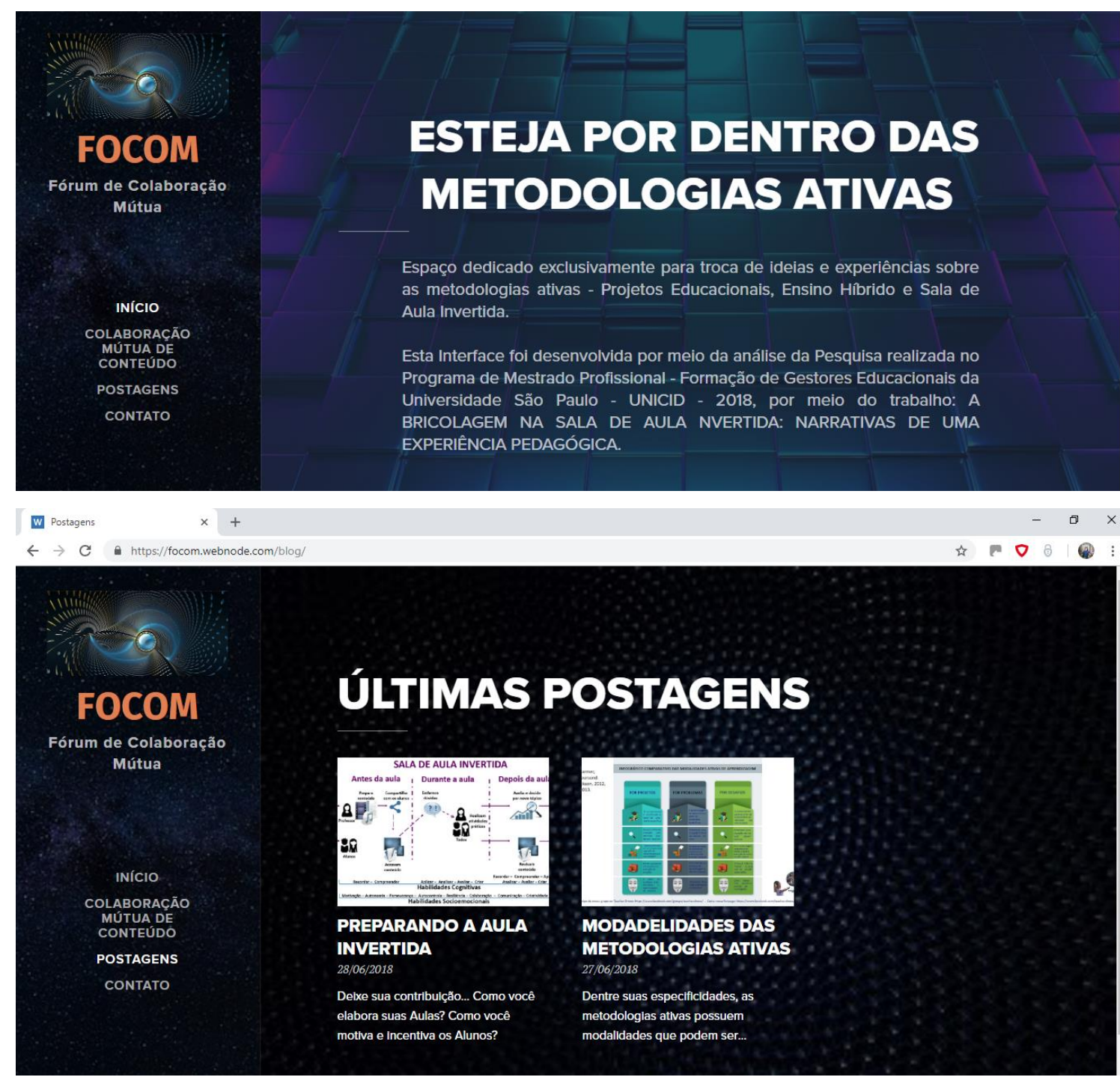




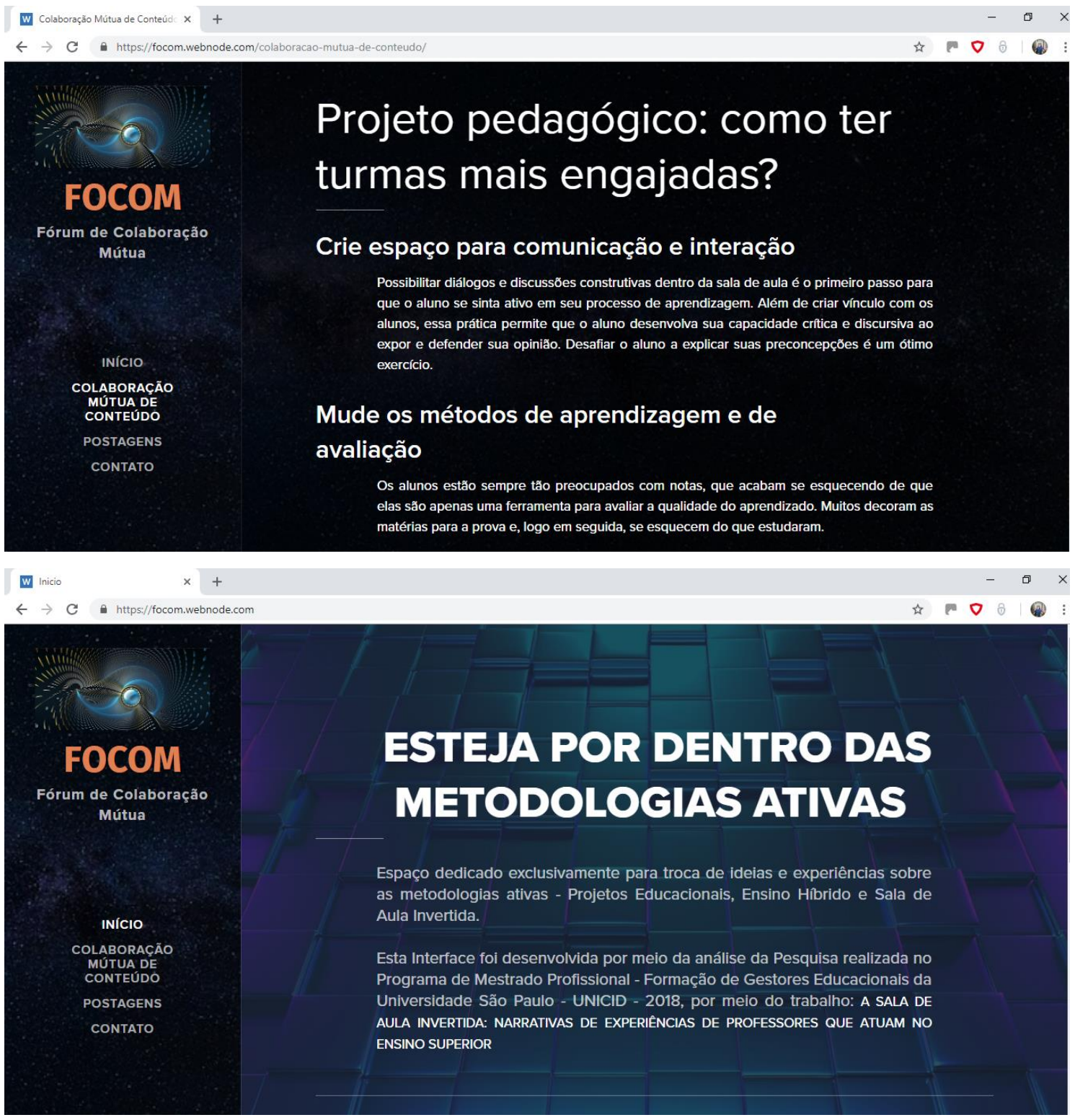

A recepção do blog pelos professores, tem ocorrido de maneira positiva e atendido a algumas expectativas, de acordo com os resultados de pesquisa realizada pela instituição. Os acessos e as divulgações de postagens estão abertos aos professores. Para manter a divulgação do blog entre os professores, é promovida uma publicação do link do blog na sala dos professores, mantendo assim o canal de colaboração mútua ativo e atualizado pelos próprios professores.

Sabemos que o blog, por si só, não pode resolver todas as questões que estão emergindo no contexto do trabalho com a aula invertida, pois muitas dizem respeito à necessidade de uma mudança de concepção do que é ensinar e aprender que rompe com representações há muito estruturadas em nossa cultura, o que não se traduz em uma tarefa simples. Porém ele pode ser um espaço para que se possa falar disso e, nessa perspectiva, 


\section{A SALA DE AULA INVERTIDA: NARRATIVAS DE EXPERIÊNCIAS \\ DE PROFESSORES QUE ATUAM NA EDUCAÇÃO SUPERIOR}

uma oportunidade de se produzir consciência sobre o que está sendo vivido em sala de aula por aqueles que dela participam.

\section{REFERÊNCIAS}

ALMEIDA, L. M. B. Levantamento dos Requisitos de uma Ferramenta Computacional de Apoio à Sala de Aula Invertida. Dissertação (Mestrado em Ensino - POSENSINO). Mossoró, Rio Grande do Norte, Brasil: Universidade do Estado do Rio Grande do Norte - IFRN, 2018.

BERBEL, N. A. N. As metodologias ativas e a promoção da autonomia de estudantes. Semina: Ciências Sociais e Humanas, Londrina, v. 32, n. 1, p. 25-40, jan./ jun. 2011. p. 29.

BERGMANN, J.; SAMS, A. Sala de aula invertida: uma metodologia ativa de aprendizagem. Rio de Janeiro: LTC, 2016.

BOGDAN, Roberto C.; BIKLEN, Sari Knopp. Investigação qualitativa em educação. Tradução Maria João Alvarez, Sara Bahia dos Santos e Telmo Mourinho Baptista. Porto: Porto Editora, 1994.

BORGES, M. R. O planejamento por competências no ensino superior: Uma análise da percepção dos professores. Dissertação (Mestrado em Metodologias para o ensino de linguagens e suas tecnologias). Londrina, Paraná, Brasil: Universidade Pítagoras UNOPAR, 2017.

DELORY-MOMBERGER, C. A condição biográfica: ensaios sobre a narrativa de si na modernidade avançada. Natal: EDUFRN, 2012.

FREIRE, P. Pedagogia do oprimido. Rio de Janeiro: Paz e Terra, 1970. Educação como prática da liberdade. Rio de Janeiro: Paz e Terra, 1989. Pedagogia do oprimido. Rio de janeiro: Paz e Terra.

FURLANETTO, E. C. Como nasce um professor? São Paulo: Paulus, 2003.

JOSSO, M. C.. Caminhar para si. Porto Alegre: EDIPUCRS, 2010. 


\section{A SALA DE AULA INVERTIDA: NARRATIVAS DE EXPERIÊNCIAS DE PROFESSORES QUE ATUAM NA EDUCAÇÃO SUPERIOR}

JOVCHELOVICH, B. S. Entrevista narrativa. Petrópolis: Vozes, 2002.

KHAN, S. (2013). Um mundo, uma escola. Rio de Janeiro: Intrínseca.

KINCHELOE, J. L. Pesquisa em educação: conceituando a bricolagem. Porto Alegre: Artmed, 2007.

LAGE, G. J. P.; TREGLIA M. Inverting the Classroom: A Gateway to Creating an Inclusive Learning Enviroment. The Jounal of Economic Education, Bloomington, v. 31, p.30-43, mar/2010.

LARROSA, J. Tecnologias do eu e educação. Petrópolis: Vozes, 1994.

LARROSA, J. Notas sobre a experiência e o saber de experiência. Petrópolis: Vozes, 2002.

LÉVY, P. As tecnologias da inteligência: o futuro do pensamento na era da informática. Rio de Janeiro: 34, 1993.

Cibercultura. São Paulo: 34, 1999.

MILHORATO, P. R. (2 de setembro de 2016). Desafios e possibilidades da implantação da metodologia sala de aula invertida. Dissertação (Mestrado Profissional em Administração). Minas Gerais, Pedor Leopoldo, Brasil: Fundação Pedro Leopoldo.

MORAN, J. Mudar a forma de ensinar e de aprender. Transformar as aulas em pesquisa e comunicação presencial-virtual. Interações, p. 57-72, 2000.

MORGAN, D. \& KRUEGER, R. A. (1993). When to use focus group and why. Em D. Morgan (Org.), Successful focus group: Advancing the state of the art (pp. 3-20). Newbury Park, CA: Sage.

POWELL, R. A.; SINGLE H. M. Focus groups. In: International Jounal for Quality in Health Care, v. 8, n. 5, p. 499-504, 1996.

SCHÜTZE, F. Pesquisa biográfica e entrevista narrativa. In: WELLER, W.; PFAFF, N. (Org.). Metodologias da pesquisa qualitativa em educação: teoria e prática. 2. ed. Petrópolis: Vozes, 2011. p. 210-222.

SPITZCOVSKY, D.. Canal do Ensino. Disponível em: $<$ https://canaldoensino.com.br/blog/conheca-o-novo-conceito-da-sala-de-aulainvertida>. Acesso em: 23 maio. 2017. 


\section{A SALA DE AULA INVERTIDA: NARRATIVAS DE EXPERIÊNCIAS DE PROFESSORES QUE ATUAM NA EDUCAÇÃO SUPERIOR}

SUHR, I. Desafios no uso da sala de aula invertida no ensino superior. R. Transmutare, Curitiba, v. 1, n. 1, p. 4-21, jan./jun. 2016.

TARDIF, M. ; LESSARD, C. O trabalho docente. Elementos para uma teoria da docência como profissão de interações. Tradução de João Kreuch. Petrópolis: Vozes, 2005.

VALENTE, J. A. Organizador: Computadores e Conhecimento - Repensando a Educação. São Paulo: UNICAMP/NIED, 1998. 